$9(1)(2020) 19-23$
Indonesian Journal of Early Childhood
Education Studies

\title{
The Use of Games Virus Hunter in Pandemic COVID-19 Against Development of Early Childhood
}

\author{
Dinita Vita Apriloka ${ }^{\bowtie}$, Suyadi Suyadi, Na'imah Na'imah
}

DOI: http://dx.doi.org/10.15294/ijeces.v9i1.39153

Universitas Islam Negeri Sunan Kalijaga Yogyakarta, Indonesia

\section{History Article \\ Submitted 22 February 2020 Revised 1 May 2020 \\ Accepted 4 June 2020}

\section{Keywords}

Game Hunter Virus; The

Development Cognitive; Past

The Kids Early

\begin{abstract}
When this Indonesia was experiencing an outbreak of pandemic COVID-19, even the plague is happening not only in Indonesia but worldwide this is a challenge great for parents to keep the fruit of his heart that was not exposed to the virus is, in addition to the parents also become role important that should keep control of the growth and development of the fruit of this heart, especially in times of children early, which at the time these activities are limited so need a way to keep doing activities that can stimulate the growth and development of her with the good. The purpose of this study was to find out how the use of hunter virus game on child development and stimulate children when facing a COVID-19 pandemic, especially in the aspect of cognitive during the early childhood. In this study using qualitative methods with data collection techniques through observation, interviews, and documentation. Based on the result of observations and interviews with child game Hunter Virus This can be used as a media when the children are at home with the game this can introduce to the children about the virus that when this was happening. Besides, children with enthusiasm and are helped in learning about the dangers of the virus.
\end{abstract}

\section{How to Cite}

Apriloka, D. V., Suyadi, S., \& Na'imah, N. (2020). The Use of Games Virus Hunter in Pandemic COVID-19 Against Development of Early Childhood. Indonesian Journal of Early Childhood Education Studies, 9(1), 19-23.
Correspondence Author:

E-mail: dinitavitaa@gmail.com
p-ISSN 2252-8415

e-ISSN 2476-9584 


\section{INTRODUCTION}

Children are a gift that is entrusted and given by Allah SWT. Where the child is equipped with the potential are developed through a variety of ways so that aspects of its development evolved with either. The world's children are the world to play, where to play meaningful for children ages early through the game. Game of children aged early is a game that can stimulate creativity, development, and also fun for children. There is an opportunity to utilize children's interest to help them connect with the knowledge (Hawkins, 2019).

In the case of this game does not have to issue a price which is expensive but can take advantage of goods scars that exist around us, which is important in a game that has safety and quality appropriate stages of the age and interests of children. With games that are suitable for children's development, they can improve their cognitive and social skills (Boissy et al, 2014). Ingame hunter virus using a game that safe and fun for children ages early.

Development is a change in the behavior of children that shows the interaction of the maturity of living things and their environment. Development is a change from infancy to adulthood which involves various aspects of behavior and abilities. Kids will evolve with reasonable and normal if it is supported by the natural surroundings, the environment that is quite healthy and well. The development of the child will be seen from the changes in the aspect of physical as the size of the body and the members of the body more and the changes are followed by aspects of the spiritual, such as increasing the ability of children in observing, remembering, thinking and willing to be something. The child's ability to adapt to the environment is the basic capital for children to be successful and happy in the future (Mayer, 2013)

Phase development of children aged early to be in time golden. Why it is said to be golden because at this time the development that occurs in children is amazing (Masganti, 2015). It covers the whole aspect of the development of the child. Where children aged early have a sense of want to know the height and nature holistic. The development is defined as the process of change in the physical, structural neurological, behavioral, and nature of which are formed by regularly and has the function of the complex. In research it has been many who tried to investigate the development of children age early with various media games, will be but the research that when these researchers did try to create a variety of games that take advantage of items that exist around us, in addition to making a child happy in play children get learning that the produce of playing hunter virus.

The virus pandemic began to shock the world since the end of 2019 with the emergence of a new virus known as coronavirus disease 2019 (COVID-19) which caused quite a high level of concern, because no vaccine had been found that could cure the virus. This virus began to be found in Indonesia in February 2020, which was supported by page halodoc.com Presiden Jokowi made an announcement that found two patients who were positive COVID-19 in Indonesia. Since then the spread of the virus that occurred in Indonesia increased and spared to various regions in Indonesia that have an impact on the economy, health, and education. As that was happening when this in almost the whole world to experience the incidence of this, the incidences of which many were infected since the pandemic COVID-19. Pandemic COVID-19 which is an outbreak of the virus first in Wuhan China (Yuliana, 2020) which is spread by rapid and extensive that lead to potential patients infected increased until the patient dies reaches 3.500 even more patients who died due to the infection of the virus (Huang et al., 2020).

Incident that occurred when this makes all the people must remain to be in the house so that the spared of the virus COVID-19 does not rise to break the chain spared of the virus, so that in case this much experience complaint since continued to be at home, as well as children who always want to play free but at the moment is the world playing them is limited. Factors that could restore the psychological development of the child is the person adults who care and support (Bartlett, 2020) in the life of a child to help the growth and development of children ages early.

Game hunter virus is a game for children ages early which was developed from the game the other and using goods scars that exist around us. The game is aimed to develop aspects of the development of cognitive children and introduce to the children about the virus, how the shape and that only the names of the virus. The game hunter virus some aspects of the development of children can be developed is optimal especially the creativity of children, where creativity is the ability to think in a way that is not usual in resolve a problem (Debeturu \& Wijayaningsih, 2019). As in this game aspects of cognitive development, physical motoric, and language when the child is doing or using the game hunter virus. Besides 
that, the game is the child feel happy because when in a state where the pandemic COVID-19 the child feels saturated and bored they can play the game is when just when they are bored.

The game is more aimed at early age children, namely 2 to 6 years. Which in this game aims to improve the development of children who when in a pandemic period the child feels bored at home and when it is also the role of parents and assisted by the role of the environment to keep stimulating the child's development so that it continues to develop properly. Game hunter virus is an alternative that is suitable to be done and given to children when bored with distance learning activities and or just stay at home. This game is made very easy because it utilizes used materials that are around the house and environmentally friendly. Besides, it is safe if played by children.

In fact that happened the game and the child almost not be separated, when we think about children, surely just thought we would be led to the association of the play, thus educating was still through the play so that the stimulus child develops are optimal in all aspect of it and be private are and one of the ways that all of it is optimal to stimulate children through games that can stimulate the stimulus.

The use of play methods for children must be flexible and follow the abilities and interests of children. But still, a lot of us find activities to play material is burdensome, especially with the situation and conditions of pandemic COVID-19 is very restricted to seek materials to exit the house and how to play that made the children quickly bored. It is making children less comfortable and less to enjoy the game. Tools game that we created in addition to making children happy instrument game educative helpful to improve the creativity of children ages early. The purpose of this study was to find out how the use of hunter virus game on child development and stimulate children when facing a COVID-19 pandemic, especially in the aspect of cognitive during the early childhood

\section{METHODS}

The research is using research qualitative who do not use the procedure of calculation is statistical. The subjects of the research is on the use of game hunter virus to the early childhood development gaes 2 to 6 years. While the object of the research this is the future of children beginning to use the game hunter virus that is carried in Canden Rt 05 District of Jets Bantul, Yogya- karta. Data collection techniques in this study were observation, interviews, and documentation. In observation of the writer use observation participatory which the authors are involved directly in the activities of everyday people who are being observed, and while the interviews were conducted by using interview semistructured which are not directly ask and give learning to the children about what the virus and Technical analysis of the data it uses data reduction (Sugiyono, 2016). Data reduction is carried out with a simple selection process and attention to children based on the results of interviews and observations.

\section{RESULTS AND DISCUSSION}

The benefits of playing in addition to being a means of entertainment for children to play invites children to social interaction and build cooperation. Social ability is a child's behavior that describes a non-individualistic relationship which includes social participation and rejection of disruption (Rizzo, 1990).

When this pandemic with games can make children happy because when in doing so not only play the child feels but education in the game is applied to stimulate its development (Ayu, 2018).

The game tool is a tool that can stimulate as a distributor of the ability to work with children (Andang, 2006). The game tool is a tool to play. While the educational game tool is a play tool that can produce certain development indicators. From educational toys, children can improve their abilities and understanding naturally or naturally. One of the characteristics of games that are categorized as educational games is to have educational value in the game.

Past childhood early, from about ages 2 to 6 years, as the stage preoperational, for children not yet ready to be involved in the operation or manipulation of mental requires thinking logically (Papalia et al., 2008). At this time children begin to receive stimulation, although it is still limited. But even children have entered the social environment.

The hallmark of this stage is that children begin to be able to use mental operations that are rarely and logically inadequate. In this stage, children begin to present their world with words, shadows and images. Symbolic thoughts go beyond simple connections of sensory information and physical action. In this game hunter virus.

In UU Sisdiknas No. 20 of 2003 article 1 paragraph 14 that a coaching effort aimed at children from birth to the age of six years is carried out through the provision of stimuli to help 
the child's physical and spiritual growth and development. Kids age of early life in the world game. That which can grow aspects of the development of the child. Playing a thing important for children, activities play while learning has become a character in the education of children of age early. Observing the environment is part of play, adults and friends beingclose to the child's life is an object that is observed and imitated by the child (Muhammad, 2011).

The world of children ages early is the world play and learning done with or while playing ones engages all of the child's senses (Sudarsana, 2018). As with anything that we see and we observe the child as learning by way of play, because the learning of children ages early was the way to play and play, from games that can build the attitude and character of the child. Because in essence playing and games children aged early is a means of socialization and exploration for children.

The use of game hunter virus priority to the development of children on aspects of cognitive early childhood. Cognitive constitutes psychiatric realm centered on the brain and associated with willand affection (Srianis et al., 2014)

Game hunter virus can be said as one of the alternatives in the study, one of the ways that can be done when children feel bored when on the sidelines of the time with a fun game. It can be seen from the enthusiastic children at the time of doing the game and learn about the virus that when this was happening in the world. They were very interested and participated as well in the game are. It is can be seen from the results of the documentation that is obtained when doing a game hunter virus.

Kids ages early to have characteristics that vary. Teachers and parents must be able to place themselves in child development in other words does not impose personal will on the child because it will greatly impact future developments (Khairi, 2018). By, therefore, before making tool game educative up to first require planning that is designed specifically as a tool to help optimize the learning and development of children. The process of making APE hunter virus first provides tools scars that exist around us such as, cardboard, scissors, paper figures, glue, stick ice, clips, rubber, dynamo, former as a mover, a magnet as a bullet. The material is used to use materials that safe for future children early and was not hurt.

Second after the appliance game educative already be introduced the first game that will be used, then explain to the children about the virus, all kinds of viruses, what tasks the virus and other. Furthermore, a third if the child already knows about the virus show or demonstrated in children on how to use games and children tried to play a game hunter virus it with sambal directed and explain virus what that shot like that shown in Figure 1 and 2.

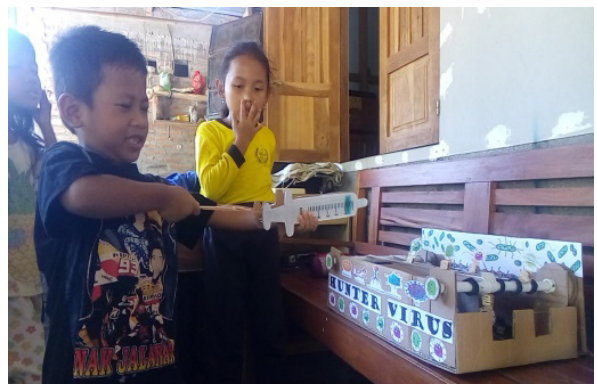

Figure 1. Is doing a Game Hunter Virus

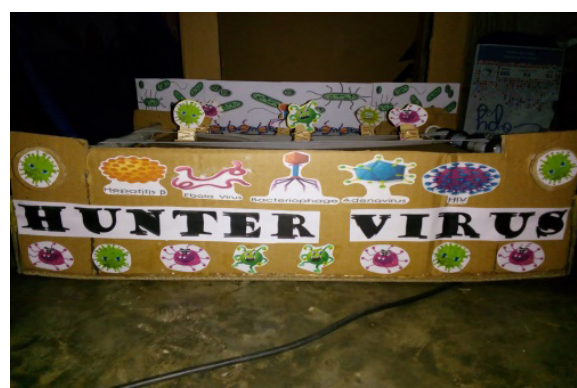

Figure 2. Game Hunter Virus

Children and games are two notions that are almost inseparable from one another. Thinking about children always creates associations about play (Aisyah, 2017). Through the game that are not directly teach and train the children to face the situation evident that occur when pandemic COVID-19, so that children know how to protect themselves from viruses, knowing viruses anything just that are around and can train the child to maintain cleanliness that is not exposed to the virus.

Aspects that are in the game hunter virus include aspects of the development of the motor when it is being played the game, aspects of cognitive who developed the children about recognizing the virus, identify the types of viruses and so on, further aspects of the language contained within the game hunter virus can help the child to talk and recognize about viruses and aspect of psychosocial the maintaining the cleanliness of oneself, the environment around so that spared from the virus and the latter is improving aspects of social-emotional child.

From the whole aspects that exist in the game hunter virus build and play a role which is very important in a situation of pandemic COVID-19 against a child when being there at home 
in a time long.

\section{CONCLUSION}

Based on the results studied and observed that during the pandemic COVID-19 children were bored at home with activities that according to the child just like that there was no difference. therefore the role of family and environment must be mutually sustainable in utilizing the situation that is happening. because the growth and development of children will continue to grow, but if it is not stimulated properly there will be a slight obstacle in the growth and development stage. so in this study, researchers tried to make a game that uses used goods that are around the house into a toy that can educate children about the state of the pandemic COVID-19 through the game hunter virus.

\section{REFERENCES}

Aisyah, A. (2017). Permainan Warna Berpengaruh Terhadap Kreativitas Anak Usia Dini. Jurnal Obsesi: Jurnal Pendidikan Anak Usia Dini, 1(2), 118-123.

Andang, I. (2006). Game Edukasi Menjadi Cerdas dan Ceria Dengan Permainan Edukatif. Pilar Media

Boissy, A., \& Erhard, H. W. (2014). How studying interactions between animal emotions, cognition, and personality can contribute to improve farm animal welfare. In Genetics and the behavior of domestic animals (pp. 81-113). Academic Press.

Debeturu, B., \& Wijayaningsih, E. L. (2019). Meningkatkan Kreativitas Anak Usia 5-6 Tahun melalui Media Magic Puffer Ball. Jurnal Obsesi: Jurnal Pendidikan Anak Usia Dini, 3(1), 233-240.

Departemen Agama RI. (2016). Undang-undang dan Peraturan Pemerintah RI Tentang Pendidikan: Depag RI

Dym-Bartlett, J. (2020). Resources to Support Children's Emotional Welfare During the COV-
ID-19 Pandemic. Child Trends, 1(1), 1-9

Gustika, A. (2018). Upaya Meningkatkan Keterampilan Sosial dan Kerjasama Anak dalam Bermain Angin Puyuh di TK Al-Akbar Kota Jambi Tahun 2017/2018. Jurnal Ilmiah Dikdaya, 9(1), 23-31.

Hawkins, R. D., Ferreira, G. A., \& Williams, J. M. (2019). The Development and Evaluation of 'Farm Animal Welfare': An Educational Computer Game for Children. Animals, 9(3), 91.

Huang, J., Liu, F., Teng, Z., Chen, J., Zhao, J., \& Xiaoping, W. (2020). Care for the phychological status of frontline medical staff fighting against covid-19. Infectious Diseases Society of America, 1-13.

Khairi, H. (2018). Karakteristik Perkembangan Anak Usia Dini dari 0-6 Tahun. Jurnal Warna, 2(2), 15-28.

Masganti. (2015). Psikologi Perkembangan Anak Usia Dini. Medan: Perdana Publshing.

Mayar, F. (2013). Perkembangan sosial anak usia dini sebagai bibit untuk masa depan bangsa. $\mathrm{Al}-\mathrm{Ta}$ lim Journal, 20(3), 459-464.

Muhammad, H. (2011). Petunjuk Teknis penyelengaraan Taman kanak-kanak. Jakarta: Kemendiknas

Papalia, D. E., Wendkos, O. S., \& Feldman, R. (2008). (Psikologi Perkembangan) Human development. Jakarta: Kencana.

Rizzo. (1990). Friendsip Developmen Among Cildren in Scool. Norwood. New Jersey: Ablex Publishing Corporation.

Srianis, K., Suarni, N. K., Ujianti, P. R., \& Psi, S. (2014). Penerapan Metode Bermain Puzzle Geometri Untuk Meningkatkan Perkembangan Kognitif Anak Dalam Mengenal Bentuk. Jurnal Pendidikan Anak Usia Dini Undiksha, 2(1).

Sudarsana, I. K. (2018). Membentuk Karakter Anak Sebagai Generasi Penerus Bangsa Melalui Pendidikan Anak Usia Dini. Purwadita: Jurnal Agama dan Budaya, 1(1).

Sugiyono. (2016). Metode Penelitian Kombinasi (Mixed Methods). Bandung: Alfabeta.

Yuliana. (2020). Corona Virus Diseases (Covid-19). Wellness and Healty Magazine, 2(1), 187-192. 